\title{
ULAMA BANJAR KHARISMATIK MASA KINI DI KALIMANTAN SELATAN: Studi Terhadap Figur Guru Bachiet, Guru Danau, dan Guru Zuhdi
}

\author{
Mujiburrahman, M. Zainal Abidin, dan Rahmadi*
}

\begin{abstract}
Artikel ini meneliti tiga figur ulama kharismatik masa kini yang ada di Kalimantan Selatan. Figur yang diangkat dalam tulisan ini, yaitu K. H. Muhammad Bachieth (Guru Bachieth); K. H. Asmuni (Guru Danau) dan K. H. Abmad Zubdiannor (Guru Zuhdi). Ketiga ulama Banjar yang dibahas menunjukkan ciri-ciri seorang tokoh kharismatik berdasarkan teori kharisma dalam sosiologi. Mereka adalah tokoh-tokoh yang memiliki keistimewaan, dan tampil di saat krisis, baik krisis sosial yang tengah terjadi, ataupun kerisis kepemimpinan ulama. Masing-masing tokoh memiliki pesona, yang mampu memukau ribuan khalayak yang setia mendengarkan ceramab-ceramabnya. Ia seolab memiliki kekuatan magnetik, yang menyerap orang-orang di sekelilingnya untuk medekat. Meskipun sama-sama memiliki kharisma, masing-masing tokoh memiliki keunikannya sendiri-sendiri. Latarbelakang sejarah intelektual mereka memang tidak sama, meskipun secara garis besar masib berada dalam jalur keulamaan tradisional. Mereka juga menjadi tokoh di wilayah yang berbeda, dengan jemaah yang berbeda pula
\end{abstract}

Kata kunci: ulama Banjar, kharismatik, krisis, ulama tradisional

\section{Pendahuluan}

Kalimantan Selatan merupakan provinsi yang dihuni oleh mayoritas suku Banjar. Orang Banjar dikenal sebagai pemeluk agama Islam. Berdasarkan sensus yang ada, jumlah pemeluk Islam di Kalimantan Selatan mencapai lebih dari 97\% (Suryadinata 2003: 65-68). Jumlah yang besar ini tentu bukan sesuatu yang terwujud secara tiba-tiba. Ia adalah hasil dari usaha-usaha dakwah yang dilakukan, terutama oleh tokoh-tokoh agama Islam yang disebut 'ulama'. Karena itu pula, para ulama memiliki kedudukan penting dalam kehidupan masyarakat Banjar hingga sekarang.

*Tim Peneliti Fakultas Ushuluddin IAIN Antasari Banjarmasin. 
Kedudukan dan peran ulama di masyarakat Banjar telah mengalami perkembangan yang cukup dinamis dari masa ke masa. Hal ini terutama disebabkan oleh perubahan sosial, politik dan budaya yang terjadi di sepanjang sejarah masyarakat Banjar. Perubahan-perubahan tersebut bahkan tidak hanya menyangkut kedudukan dan peran sosial seorang ulama, melainkan juga menyangkut persepsi masyarakat tentang berbagai kriteria yang harus dimiliki seseorang yang dianggap sebagai ulama.

Dinamika keberadaan ulama Banjar dapat dilihat dari penggunaan sebutan yang dinisbahkan kepadanya. Kata 'ulamâ' diambil dari Bahasa Arab, sebagai bentuk jamak dari kata 'alim, artinya orang yang berilmu. Karena ilmu yang mula-mula berkembang dalam Islam adalah ilmu agama, maka 'ulamâ' biasanya adalah orang-orang yang menguasai ilmu-ilmu agama Islam. Sedangkan dalam Bahasa Indonesia, kata 'ulama' digunakan sebagai bentuk tunggal, bukan jamak. Dalam hal penggunaan, kata 'ulama' biasanya digunakan sebagai sebutan identitas yang bersifat umum, yang dikenakan kepada seorang pemuka agama Islam. Karena sifatnya umum, jarang sekali didengar orang memanggil seseorang dengan 'pak ulama' atau 'ibu ulama'. Untuk memanggil seseorang secara khusus, biasanya digunakan sebutan lain sesuai dengan budaya setempat. Misalnya, orang Jawa menyebut ulama dengan 'kiyai'. Sedangkan dalam budaya Banjar, terdapat sebutan-sebutan seperti 'tuan guru', 'syekh', 'datu', 'qadhi', 'mufti', 'mu'allim' dan 'ustadz' atau 'ustadzah'.

Berbagai sebutan untuk ulama seperti 'guru', 'mu'allim' dan 'ustadz' secara jelas dan langsung menunjukkan bahwa seorang ulama adalah pendidik. Karena itu, membicarakan ulama tidak bisa terlepas dari pendidikan, baik pendidikan yang pernah ia jalani, ataupun pendidikan yang dia rintis untuk masyarakatnya. Perkembangan sosial, budaya dan politik yang terjadi dari masa ke masa, tentu turut mempengaruhi jenis pendidikan apa yang ditempuh oleh seorang ulama di satu sisi, dan model pendidikan seperti apa yang mereka kembangkan untuk masyarakat di sisi lain. Kedua sisi ini saling berhubungan dalam membentuk dan menjaga otoritas keagamaan ulama di masyarakat.

Tidak ada informasi yang rinci mengenai siapa ulama yang pertama kali mengajarkan agama Islam di wilayah Banjar. Islam diperkirakan masuk ke daerah ini pada abad ke- 16. Riwayat yang didapatkan dalam Hikajat Bandjar 
menyebutkan, Sultan Banjar pertama yang memeluk agama Islam adalah Pangeran Samudera, yang kelak disebut Sultan Suriansyah (w. 1550). Ketika itu, sang pangeran ingin merebut kembali kekuasaan dari pamannya, Tumenggung. Karena merasa tidak mungkin mengalahkan pasukan pamannya, ia kemudian meminta bantuan Kerajaan Demak di jawa. Demak menyatakan siap membantu dengan syarat sang pangeran mau memeluk Islam. Pangeran Samudera pun bersedia memeluk Islam (Ras 1968). Maka dikirimlah pasukan dari Demak bersama seorang penghulu bernama Khatib Dayyan, yang akan mengajarkan agama Islam. Singkat cerita, sang pangeran akhirnya berhasil meraih kekuasaan. Gelar Sultan Suriansyah untuk sang pangeran, konon diberikan oleh seorang ulama keturunan Arab, yang namanya tak disebutkan (Bondan 1953 :14-15).

Meski Islam dinyatakan sudah masuk ke wilayah Banjar sejak abad ke16, namun Islamisasi yang intensif baru mulai di abad ke-18 dengan tokoh sentralnya Muhammad Arsyad al-Banjari (1710-1812 M). Ia merupakan sosok ulama Banjar paling awal, yang sejarah hidupnya menjadi contoh bagi ulamaulama di kemudian hari. Pada usia 30 tahun, Arsyad dikirim oleh Sultan Tamjidillah (1734-1759 M) ke tanah suci untuk berhaji sekaligus menuntut ilmu agama Islam. Menurut cerita, Arsyad belajar di Masjidil Haram Mekkah selama kurang lebih 30 tahun. Kemudian ia pindah ke Madinah, dan belajar di kota Nabi ini selama 5 tahun. Selama periode itu, ia tidak hanya belajar, tapi juga mengajarkan ilmu yang telah diperolehnya kepada orang lain (Tim IAIN Antasari 1989).

Arsyad al-Banjari pulang ke tanah air pada 1772 M. Setelah tiba di kesultanan Banjar, ia diberi Sultan Tahmidullah II (1781-1801 M) sebuah lahan yang cukup luas. Di situ kemudian dibagun perumahan sekaligus langgar sebagai tempat beribadah dan belajar. Lahan ini kemudian dikenal dengan nama 'Dalam Pagar', konon karena dulu tempat ini dikelilingi dengan pagar. Kita tidak tahu persis bagaimana model pembelajaran yang dilaksanakan alBanjari ketika itu. Namun kiranya tidak akan meleset kalau kita katakan bahwa pengajian yang dia berikan mengikuti sistem balaqah sebagaimana yang pernah ia alami di Haramain. Sistem balaqah ini, di mana murid-murid duduk 
berkeliling di hadapan guru, dalam budaya Banjar dikenal dengan sebutan mangaji baduduk.

Selain mengajar, Arsyad al-Banjari juga menulis buku-buku agama, yang kemungkinan dijadikannya sebagai bahan pembelajaran. Hampir semua karya Arsyad al-Banjari yang sampai kepada kita ditulisnya dalam Bahasa Melayu Arab, dan hanya sedikit yang ditulis dalam Bahasa Arab. Dengan menggunakan Bahasa Melayu, tampak jelas bahwa ia ingin membantu masyarakat agar dapat dengan lebih mudah memahami ajaran-ajaran Islam. Patut dicatat bahwa pada saat itu, Bahasa Melayu sudah menjadi lingua franca, yakni bahasa bersama yang digunakan berbagai suku di Nusantara untuk berkomunikasi satu sama lain. Ini pula sebabnya mengapa karya-karya Arsyad al-Banjari tidak hanya dikenal di masyarakat Banjar, melainkan juga di Nusantara.

Ketika itu, orang-orang yang menjadi murid Arsyad al-Banjari terdiri dari keluarganya, anak-anak dan cucu-cucunya, di samping orang-orang yang bukan dari keluarganya sendiri. Arsyad al-Banjari dianugerahi usia panjang (102 tahun) dan memiliki isteri yang banyak, dan karena itu keturunannya cukup banyak pula. Sebagian dari keturunannya ini kemudian ada yang menjadi ulama dan melanjutkan dakwah Islam ke berbagai daerah di Kalimantan, bahkan hingga ke Sumatra dan Malaysia. Demikian pula, murid-murid Arsyad alBanjari yang bukan dari keluarganya sendiri, juga kemudian mengajarkan agama di masyarakat.

Jika diperhatikan ulama-ulama yang berperan di masyarakat Banjar di akhir abad ke-19 hingga pertengahan abad ke-20, kebanyakan mereka mengikuti pola Arsyad al-Banjari. Mereka pergi ke Haramain untuk berhaji sekaligus menuntut ilmu agama, kemudian pulang ke kampung halaman untuk berdakwah, dan sebagian lagi ada yang membangun lembaga pendidikan dan menulis kitab-kitab agama. Para ulama yang pergi ke Haramain di akhir abad ke-19 umumnya terlebih dahulu belajar di Dalam Pagar dengan Arsyad alBanjari, baru kemudian berangkat ke sana. Sedangkan mereka yang ke Haramain di abad ke-20, kebanyakan sudah belajar ilmu agama di berbagai lembaga pendidikan yang sudah tersebar di Kalimantan Selatan seperti di Nagara, Amuntai, Barabai dan Martapura (Rahmadi dkk 2009). 
Salah satu pusat pendidikan Islam di luar Dalam Pagar, yang berkembang pesat mulai akhir abad ke-19 adalah di Nagara. Jaringan ulama Nagara dapat ditelusuri sampai ke Arsyad al-Banjari. Salah seorang murid Arsyad al-Banjari adalah Sa'duddin (Datu Taniran). Selain belajar di Dalam Pagar dengan al-Banjari, Sa'duddin juga belajar ke Haramain. Setelah pulang, ia kemudian mengajar agama di Taniran. Di antara murid-muridnya di Taniran adalah Muhammad Thahir asal Nagara, yang juga melanjutkan studi ke Haramain. Dua orang teman Muhammad Thahir yang juga berasal dari Nagara adalah Abdurrahman dan Azhari. Tiga orang inilah yang menjadi tokoh ulama Nagara di akhir abad 19 hingga paruh pertama abad ke-20. Pada masa itu, di Nagara berkembang apa yang disebut langgar barangkap (musalla bertingkat dua), sejenis pesantren mini yang menjadi tempat penginapan santri sekaligus tempat ibadah dan belajar. Ulama asal Amuntai dan perintis Pesantren Rasyidiyah Khalidiyah, Abdurrasyid, pernah belajar di Nagara. Begitu pula, ulama terkenal dari Barabai, Muhammad Ramli, orangtua dari Mahfuz Amin, pendiri Pesantren Ibn al-Amin Pemangkih (berdiri 1958), juga pernah belajar di Nagara (Rahmadi dkk 2009: 168-178; Mandan 2008: 66-70).

Selain itu, ada perubahan penting yang terjadi di abad ke-20, yaitu orang-orang Nusantara, termasuk orang-orang Banjar, tidak lagi hanya pergi ke Haramain untuk menuntut ilmu, melainkan juga ke Mesir, tepatnya di Universitas al-Azhar. Hal ini disebabkan karena Haramain telah dikuasai oleh Dinasti Ibnu Saud yang beraliran Wahabi, yang bagi kebanyakan mereka tidak cocok dengan paham keagamaan yang selama ini berkembang di tanah air. Namun di Mesir sendiri, mereka menemukan model pendidikan yang sudah diperbarui oleh Muhammad Abduh (1845-1905 M) dan murid beliau, Rasyid Ridha (1865-1935 M).

Di antara para ulama yang belajar ke al-Azhar pada paruh pertama abad ke-20 adalah Abdurrasyid (1885-1934 M) dari Pekapuran, Amuntai. Ia berangkat ke al-Azhar pada tahun 1912 dan kembali ke tanah air pada 1922. Setibanya di Amuntai, ia memulai dakwah dengan membuka pengajian di rumah mertuanya. Lalu pada tahun 1924, ia membangan langgar barangkap model Nagara yang telah disebutkan di atas. Kemudian ia merintis pendidikan Islam modern berdasarkan sistem klasikal dengan nama Arabische School pada 
tahun 1928. Lembaga inilah yang kemudian menjadi Normaal Islam atau Pesantren Rasyidiyah Khalidiyah, Amuntai. Setelah Abdurrasyid wafat pada 1934, ia digantikan oleh Juhri Sulaiman (1907-1972 M), seorang ulama yang juga alumni al-Azhar (Rahmadi dkk 2009: 205-207).

Sementara itu, di Martapura terjadi suatu perkembangan yang cukup penting pula di bidang pendidikan Islam. Pada tahun 1914, seorang ulama bernama H. Jamaluddin, berinisiatif mendirikan madrasah bernama al-Imâd fi Ta'lim al-Awlâd dengan sistem klasikal. Tidak banyak informasi yang saya ketahui tentang sosok H. Jamaluddin ini. Yang jelas ia adalah aktivis gerakan Sarekat Islam. Pada masa berikutnya, madrasah ini dikelola oleh Nahdlatul Ulama (NU) Cabang Martapura. Madrasah ini kelak dikenal dengan Pesantren Darussalam, Martapura, yang hingga kini menjadi salah satu pusat pendidikan calon-calon ulama yang berpengaruh, khususnya di Kalimantan Selatan (Syaharuddin 2008: 178;183).

Pada paruh kedua abad ke-20, jalur pendidikan ulama masih tetap mengikuti jalur lama, yakni ke Haramain atau ke Mesir. Namun ada beberapa perkembangan baru yang sebelumnya belum ada. Pertama, tidak semua orang Banjar yang belajar di Haramain sekadar mengikuti halaqah di Masjidil Haram. Beberapa orang siswa pesantren yang berprestasi, berhasil mendapatkan beasiswa dari pemerintah Saudi Arabia untuk kuliah di Universitas Umm alQura', Mekkah atau di Universitas Madinah. Tentu saja ideologi yang dikembangkan di dua universitas itu adalah Salafi-Wahabi. Meskipun setelah pulang kampung, mereka tidak otomotis menjadi penyiar paham Salafi-Wahabi. Kedua, sebagian ulama Banjar tidak lagi pergi ke luar negeri, melainkan cukup belajar di pesantren yang ada di Kalimantan Selatan atau di Jawa saja. Kebanyakan mereka belajar di Darussalam atau Ibn al-Amin, lalu kemudian melanjutkan ke Pesantren Datu Kelampayan, Bangil. Ada pula di antara mereka yang studi di Pondok Modern Gontor (Ponorogo), atau di al-Syafi'yah (Jakarta), dan lain-lain. Jumlah mereka ini cukup banyak, dan sebagian setelah tamat menjadi ulama di masyarakat. Ketiga, sebagian orang Banjar yang pergi ke luar negeri untuk belajar agama, mereka tidak lagi hanya pergi ke Haramain atau ke Mesir, tapi juga ada yang ke Pakistan, Malaysia, dan Hadramaut. Ini 
menunjukkan semakin banyaknya jalur pendidikan yang bisa dilalui oleh seorang calon ulama.

Demikianlah gambaran dinamika ulama di Kalimantan Selatan, yang terus mengalami perkembangan hingga saat ini. Keberadaannya dari masa ke masa terus memainkan peran sentral kehidupan umat Islam di kawasan ini. Hal ini tidak lain, karena selain peran ulama sebagai pendidik, pemimpin ibadah dan pejuang politik, perannya yang lebih penting adalah sebagai konsultan bagi masyarakat dalam menghadapi berbagai persoalan hidup. Seorang ulama di masyarakat Banjar biasanya melayani masyarakat nyaris tiap hari, siang dan malam. Pintu rumahnya kadang diketuk tengah malam atau dini hari oleh orang yang meminta pertolongannya. Ada yang bertanya soal hukum agama. Ada yang datang minta bantuan doa untuk anaknya yang sakit. Ada yang datang minta nama untuk bayi yang baru lahir. Ada pula yang datang karena sakit hati menghadapi anak yang nakal, atau suami yang kawin lagi. Pokoknya segala macam persoalan hidup, diajukan kepada sang ulama.

Peran ulama sebagai pengayom dan pelipur hati masyarakat itu dapat pula terjadi secara tidak langsung, yakni di pengajian-pengajian yang ia berikan. Kadang masyarakat menyukai pengajian seorang ulama karena merasakan kedamaian dalam mendengarkan petuah-petuahnya. Hati yang sedih dan gundah menjadi tenang oleh siraman nasihat-nasihatnya. Boleh jadi pula masyarakat menyenangi ceramah seorang ulama karena banyak lelucon darinya, sehingga para pendengarnya terhibur dan tertawa. Adapula seorang ulama yang disukai jamaahnya karena suaranya yang merdu menyentuh kalbu. Mungkin pula ia disenangi masyarakat karena kemampuannya menjelaskan konsepkonsep agama yang rumit menjadi mudah dan aktual bagi kehidupan seharihari.

Selain membuka sekolah, madrasah dan pesantren, kegiatan para ulama sebagai pendidik dan pembimbing masyarakat adalah memberikan ceramah atau pelajaran agama secara rutin di berbagai pengajian. Sangat mungkin bahwa kegiatan memberikan pengajian dan ceramah ini sudah dilakukan ulama sejak periode awal Islam masuk ke daerah Banjar di abad ke-16. Namun tak ada keraguan pada kita bahwa sejak abad ke-18, yang dirintis oleh Arsyad alBanjari, dan abad-abad berikutnya yang diteruskan oleh murid-muridnya, 
pengajian-pengajian sudah dilaksanakan oleh para ulama di berbagai tempat di Kalimantan Selatan. Melalui pengajian-pengajian itulah akhirnya Islam menyebar dan meresap dalam kebudayaan Banjar.

Kini pengajian-pengajian sangat marak di masyarakat. Namun tidak diketahui berapa persis jumlah pengajian yang ada di Kalimantan Selatan saat ini. Yang jelas, untuk Kota Banjarmasin saja, diperkirakan terdapat lebih dari 100 pengajian. Sangat mungkin kalau ditotal secara keseluruhan, jumlah pengajian di Kalimantan Selatan mencapai 1000 buah. Pengajian-pengajian itu dilaksanakan di berbagai tempat. Ada yang di rumah secara bergiliran, seperti yang dilakukan oleh perkumpulan Yasinan. Bisa pula pengajian dilaksanakan di rumah sang ulama sendiri, atau di rumah orang kaya yang memiliki ruang yang cukup luas. Ada pula yang di masjid atau langgar. Ada pula yang di 'majelis taklim', yakni suatu tempat khusus yang dipakai untuk pengajian. Ada pula yang di kantor-kantor, khususnya untuk kalangan eksekutif.

Materi yang diajarkan juga beragam. Pada umumnya materi pengajian mencakup lima jenis ilmu keislaman yaitu: Tafsir, Hadis, Tauhid, Fiqh dan Tasawuf. Biasanya, ada kitab tertentu yang dipakai dalam pengajian tersebut. Misalnya, tafsir yang diajarkan adalah Marâh Labîd, Hadisnya Shabîh Bukbârî, tauhidnya Kifâyat al-'Awâm, Fiqhnya, I'ânat al-Thâlibîn, dan tasawufnya Ibyâ' Ulùm al-Dîn. Kadang-kadang, ada pula ulama yang mengajarkan kitab karangannya sendiri, yang umumnya ditulis dalam Bahasa Melayu Arab. Selain itu, materi yang cukup populer di masyarakat adalah manakib ulama-ulama terkenal. Yang sering dibaca misalnya adalah Manakib Syekh Samman dan Syekh Abdul Qadir Jailani. Belakangan ini, manakib semakin banyak ragamnya, termasuk manakib ulama-ulama Banjar sendiri. Manakib yang cukup populer di kalangan ibu-ibu belakangan ini adalah Manakib Siti Khadijah, isteri Rasulullah saw.

Selain pengajian yang skalanya kecil, terdapat juga pengajian dengan jumlah jamaah mencapai ribuan, dan ini biasanya dipimpin oleh seorang ulama kharismatik. Keberadaan pengajian yang dipimpin oleh seorang ulama kharismatik dengan jumlah jamaahnya mencapai ribuan tentunya memiliki daya tarik tersendiri, di tengah perubahan sosial, politiak dan budaya yang sangat 
kuat menghantui masyarakat modern, termasuk yang tinggal di Kalimantan Selatan.

Di Kalimantan Selatan tokoh kharismatik paling menonjol di penghujung abad ke-20 adalah K. H. Muhammad Zaini bin Abdul Ghani yang biasa disebut dengan Guru Sekumpul atau guru Ijai yang berdomisili di Martapura. Keberadaan tokoh ini menjadikan Martapura yang dikenal sebagai Serambi Mekkah semakin menjadi sentral dalam upaya untuk menuntut ilmu agama, baik melalui lembaga pendidikan formal semacam Pondok Pesantren ataupun melalui pengajian-pengajian umum. Ulama-ulama yang muncul belakangan banyak mengidentifikasikan diri dengan Guru Sekumpul, utamanya dalam pengidentifikasian status sebagai murid beliau atau orang yang diamanahi untuk meneruskan kiprah beliau di bidang agama.

Sepeninggal Guru Sekumpul yang wafat pada bulan Agustus 2005, terjadi perubahan yang cukup signifikan dalam peta keulamaan di Kalimantan Selatan. Martapura dalam hal ini tidak lagi menjadi wilayah utama dalam pengajian-pengajian yang diikuti oleh puluhan ribu orang, tetapi menyebar ke kawasan-kawasan lain yang cukup merata seperti di Banjarmasin, Hulu Sungai Tengah, Hulu Sungai Utara, dan Balangan serta Tanjung.

Setelah era Guru Sekumpul, setidaknya ada tiga figur yang cukup menonjol yang dapat dipandang sebagai ulama kharismatik masa kini. Ketiganya, yaitu K. H. Muhammad Bachiet yang dikenal dengan sebutan Guru Bachiet, K. H. Asmuni yang lazim dipanggil Guru Danau, dan K. H. Ahmad Zuhdiannor yang biasa disebut Guru Zuhdi. Guru Bachiet membuka pengajian rutin di Barabai, Ilung, dan Paringin yang merupakan bagian dari kabupaten Hulu Sungai Tengah dan Balangan. Guru Danau membuka pengajian tetap di Danau Panggang, Bitin (keduanya di Kabupaten Hulu Sungai Utara), dan Mabuun (Kabupaten Tabalong). Sedangkan Guru Zuhdi membuka pengajian tetap di berbagai tempat di Kota Banjarmasin.

Ketiga figur tersebut di atas kiranya dapat disebut sebagai representasi dari tipikal ulama kharismatik masa kini dengan berbagai kekhasan yang dimiliki. Ketiga orang ini memiliki usia yang relatif masa muda, bahkan Guru Zuhdi usianya masih belum 40 tahun. Ketiganya juga memiliki keunikan sendiri-sendiri dalam membangun relasi dengan jemaahnya. Meski di 
masyarakat ada yang memiliki pandangan berbeda terhadap figur-figur di atas, namun yang pasti mereka memiliki jemaah yang relatif fanatik. Bahkan, mereka siap untuk terus mengikuti ke mana saja sang guru mengisi pengajian. Atas dasar pemikiran di atas, maka masalah kharisma ulama ini tentu menarik untuk dieksplorasi, khususnya di era abad ke-21 yang sarat dengan perubahan dan tantangan zaman yang berbeda.

Ada dua pokok masalah yang dibahas dalam tulisan ini. Pertama, sekitar latar belakang biografis Guru Bachiet, Guru Danau, dan Guru Zuhdi dan kedua, faktor-faktor yang membentuk kharisma mereka.

\section{Metode Penelitian}

Penelitian ini adalah penelitian lapangan (field research), yang menuntut kehadiran langsung peneliti. Ada tiga figur yang diangkat dalam penelitian ini, yaitu K. H. Muhammad Bachieth (Guru Bachieth); K. H. Asmuni (Guru Danau) dan K. H. Ahmad Zuhdiannor (Guru Zuhdi).

Data yang digali dalam penelitian ini terdiri dari data primer dan sekunder. Data primer berupa fakta-fakta, kata-kata, informasi dan tindakan yang diperoleh dari wawancara dan observasi. Data primer dalam penelitian ini terkait dengan kharisma seorang tokoh agama yang terdapat di Kalimantan Selatan. Sedangkan data sekunder berupa informasi yang berasal dari sumbersumber tertulis yang berasal dari kitab-kitab, risalah-risalah, dokumen lainnya yang relevan dengan masalah yang diteliti.

Dalam rangka memperoleh dan mengumpulkan data di lapangan digunakan beberapa teknik sebagai berikut: (1) Observasi, yaitu dengan melakukan pengamatan baik secara langsung maupun tidak langsung, yang sengaja dilakukan secara sistematis dan didukung dengan pendataan terhadap gejala yang berhasil diteliti; (2) Wawancara, yaitu dengan melakukan wawancara mendalam kepada para responden dengan mengajukan pertanyaan secara langsung dan mendalam terhadap sumber data; dan (3) Studi dokumentasi, yaitu dengan menelaah kitab-kitab, risalah-risalah, jurnal dan dokumen lain yang berkaitan dengan objek penelitian.

Dalam menganalisis data, peneliti menginventarisasi data agar mudah ditafsirkan. Catatan informal yang memuat data-data hasil dari serangkaian observasi, wawancara dan studi dokumentasi digolongkan ke dalam sub-sub permasalahan. Data-data mentah tersebut diseleksi, dirangkum dan disusun kembali dalam bentuk deskripsi yang lebih sistematis dalam laporan hasil 
penelitian. Hasil penelitian yang memuat berbagai data dan informasi tentang objek kajian selanjutnya akan dianalisis dengan menggunakan berbagai tentang kharisma, dalam bentuk analisis kualitatif.

\section{Biografi Guru Bachiet, Guru Danau, dan Guru Zuhdi}

Dalam pembahasan tentang figur ulama Banjar kharismatik masa kini, ada tiga figur ulama yang dijadikan subjek kajian, yakni Guru Bachiet, Guru Danau, dan Guru Zuhdi. Ketiga deskripsi mengenai figur ini disusun secara alfabet, tanpa melihat siapa yang paling kharismatik di antara mereka bertiga. Apabila dilihat dari senioritas maka mestinya secara berurutan adalah Guru Danau, Guru Bachiet, dan baru Guru Zuhdi.

\section{Figur Guru Bachiet}

K.H. Muhammad Bachiet atau biasa disapa "Guru Bachiet" merupakan putera dari pasangan $\mathrm{H}$. Ahmad Mugeni dan $\mathrm{Hj}$. Zainab. Guru Bachiet lahir pada 1 Januari 1966 di Telaga Air Mata (Kampung Arab), Barabai. Ayah Guru Bachiet, H. Ahmad Mughni, adalah seorang tokoh ulama di Hulu Sungai Tengah (HST) yang populer dengan sebutan "H. Amat Nagara", mengingat asal beliau dari Nagara, salah satu kecamatan yang terdapat di Hulu Sungai Selatan (HSS).

Guru Bachiet berasal dari latarbelakang keluarga yang menekuni ilmuilmu agama. Secara silsilah nasab, beliau termasuk keturunan dari ulama paling terkemuka di Kalimantan Selatan, yaitu Syekh Arsyad Al Banjari melalui jalur Syihabuddin ke Muhammad Thahir dan ke Ahmad Mugeni, yang merupakan ayah beliau (w. 1994). Semua nama-nama yang disebut dalam silsilah beliau sampai ke Syekh Arsyad Al Banjari adalah tokoh-tokoh ulama di Kalimantan Selatan.

Meski memiliki jalur silsilah nasab keluarga yang bagus, yakni keturunan Syekh Arsyad (Bani Arsyadi), yang dalam kultur Banjar dapat menjadi garansi untuk menjadikan seorang tokoh agama yang dihormati, Guru Bachiet biasanya menolak untuk berbicara tentang nasab, apalagi menonjolkannya. Namun, di kalangan murid-muridnya, perihal nasab ini sudah menjadi pengetahuan umum. Ketidakmauan sang Guru menyebut-nyebut silsilahnya ini justru semakin mengangkat kharismanya karena hal ini dianggap sebagai bukti sikap rendah hati (tawadhu) yang dimilikinya. 
Selain itu, berbeda dengan figur-figur ulama Banjar masa kini yang banyak mengkaitkan diri dengan ulama kharismatik sebelumnya, yakni Guru Sekumpul, panggilan akrab almarhum K. H. Zaini Ghani, ulama terkemuka dari Martapura, Guru Bachiet tidak terlalu mengidentikkan diri ke tokoh yang satu ini. Figur sang ayah lebih beliau tonjolkan. Menurut salah seorang dekatnya, Guru Bachiet pernah diminta oleh Guru Sekumpul untuk datang ke Martapura menemuinya berkali-kali. Baru pada panggilan yang ketujuh kalinya, Guru Bachiet bersedia menemui Guru Sekumpul. Hal ini karena Guru Bachiet terlebih dahulu meminta restu ayahnya, H. Amat Nagara, dan baru pada panggilan ketujuh, restu itu didapatkan. Diceritakan pula, bahwa pertemuan antara Guru Sakumpul dan Guru Bachiet itu berlangsung sangat akrab, semalaman penuh hingga subuh. Menurut orang dekat Guru Bachiet itu lagi, meskipun ayahanda Guru Bachiet kini telah wafat, komunikasi antara anak dan ayah ini masih terus berlangsung. Dalam seminggu, minimal dua kali ada komunikasi antara keduanya. Maka dalam menentukan kitab apa yang akan diajarkan setelah pelajaran satu kitab ditamatkan, Guru Bachiet pun meminta petunjuk ayahnya. Jelas komunikasi ini dipahami sebagai komunikasi spiritual, di antara orang-orang yang memiliki kualitas ruhani yang tinggi.

Masa kecil Muhammad Bachiet penuh dengan pengaruh nuansa keagamaan, baik dalam lingkungan keluarga maupun lingkungan pondok pesantren, dimana beliau bertempat tinggal. Pendidikan fomal yang beliau jalani hanya sampai ke jenjang kelas IV pada tahun 1976. Selebihnya, ia menjalani pendidikan non-formal, yang dimulai dari pendidikan keluarga, terutama dari sang ayah sebagai seorang ulama yang cukup disegani di Barabai. Pada tahun 1977, Bachiet muda nyantri di Pondok Pesantren Ibnul Amin, Pemangkih, HST selama lebih kurang tiga tahun. Pada tahun 1980, beliau nyantri lagi di Pondok Pesantren Darussalam, Martapura sekitar enam bulan, dan pindah ke Darussalamah, sekitar 1,5 tahun. Setelah itu kembali lagi ke Barabai, berguru kepada orang tua sendiri, dan kepada para ulama yang ada di sana seperti $\mathrm{H}$. Abdul Wahab pada bidang Fikih, H. Hasan pada bidang ilmu nahwu serta dengan $H$. Saleh juga pada bidang ilmu nahwu.

Pada tahun 1993, Muhammad Bachiet diminta oleh orang tuanya untuk pergi ke Bangil, Jawa Timur, untuk berguru dan mengaji ilmu tarekat Alawiyah dengan Habib Zein Al Abidin Ahmad Alaydrus, dari Surabaya. Setelah menerima pelajaran selama satu tahun, oleh sang guru, beliau diperintahkan 
memperkenalkan ajaran tarekat Alawiyah dengan syarat jamaahnya tidak boleh kurang dari 40 orang.

Setelah kembali ke kampung halaman di Barabai, Muhammad Bachiet mengumpulkan jamaah dari anggota keluarga sendiri, para santri dan tokoh masyarakat. Setelah 40 orang jamaah terpenuhi, mulailah beliau memperkenalkan ajaran tarekat Alawiyah. Pada awalnya, pengajian tareket ini bertempat di Pondok Pesantren Hidayaturrahman Barabai. Di tempat ini, pengajian hanya berlangsung selama 40 minggu atau 40 kali pertemuan. Namun, mengingat jumlah jamaahnya selalu bertambah, dan tempat yang ada sudah tidak terlalu memadai, maka pengajian di pindahkan ke lokasi pondok pesantren Rahmatul Ummah, yang berada satu komplek dengan tampat yang lama. Perkembangan berikutnya, nama itu kemudian berganti menjadi Nurul Muhibbin (secara bahasa artinya 'cahaya para pencinta'). Mengingat jumlah jemaah yang semakin lama semakin meningkat, Muhammad Bachiet kemudian mengajak masyarakat membangun sebuah majelis taklim. Di Lokasi pengajian yang baru ini, dapat menampung lebih dari puluhan ribu jamaah, yang areanya meliputi pondok pesantren, mushalla, dan lapangan yang cukup luas serta tempat parkir yang dekat dengan pengajian.

Dewasa ini, popularitas beliau sebagai pemimpin Tarekat Alawiyah tidak lagi sebatas di Hulu Sungai Tengah, tapi sudah merambah ke kawasankawasan lain di Kalimantan. Hal ini, karena ceramah beliau yang selalu ditranskrip oleh santri-santri beliau serta direkam dalam bentuk VCD memungkinkan jangkauan audiens tidak lagi terbatasi pada yang hadir. Setiap hari, stasiun televisi lokal yang ada di Banjarmasin menayangkan rekaman tersebut. Selain pengajian tarekat yang rutin setiap malam Selasa di Barabai, beliau juga mengisi pengajian lain di Ilung setiap malam Kamis, dan malam Rabu di Paringin, yang jumlah jamaahnya juga mencapai ribuan bahkan puluhan ribu.

\section{Figur Guru Danau}

Guru Danau merupakan panggilan akrab atau nama populer bagi Tuan Guru Asmuni. Nama "Danau" yang dilekatkan pada dirinya sebenarnya merupakan nama singkat dari tempat kelahiran dan tempat tinggalnya, Danau Panggang. Danau Panggang merupakan salah satu Kecamatan di daerah Kabupaten Hulu Sungai Utara yang terletak sekitar 24 km dari kota Amuntai. 
Saat ini (2011), Guru Danau berusia 56 tahun. Ini berarti dia lahir pada tahun 1955 di Danau Panggang. Ayahnya bernama Haji Masuni dan ibunya bernama Hajjah Masjubah. Dia merupakan anak ketiga dari delapan bersaudara. Ayahnya berasal dari daerah Danau Panggang sedang ibunya beretnis Dayak Bakumpai berasal dari daerah Marabahan yang pindah ke Danau Panggang. Dari garis ibunya Guru Danau menjadi bagian dari zuriat Syekh Muhammad Arsyad alBanjari. Sewaktu kecil, Guru Danau bernama Zarkasyi. Oleh seorang habib yang bernama Habib Salim Mangkatip nama itu diubah menjadi Asmuni. Menurut Guru Danau, Asmuni itu berarti berharga.

Guru Danau hidup di lingkungan keluarga yang sederhana dan taat beragama. Orang tuanya dahulu bekerja sebagai buruh kapal dengan pendapatan yang pas-pasan. Pendapatan yang pas-pasan itu tidak menghalangi semangat orangtuanya untuk membiayai pendidikannya di sejumlah pesantren baik yang berada di Kalimantan Selatan maupun di Pulau Jawa. Guru Danau termasuk beruntung, karena tidak banyak orang di daerahnya yang mampu dan memiliki kesempatan untuk berangkat ke Pulau Jawa untuk belajar meski dalam waktu singkat.

Guru Danau menempuh pendidikan tingkat dasar di Madrasah Ibtidaiah Pesantren Mu'alimin Danau Panggang (tamat tahun 1971) dan Madrasah Tsanawiyah Pesantren Mu'alimin Danau Panggang (tamat tahun 1974). Setelah itu dia meneruskan studinya di tingkat atas (aliyah/ulya) di Pesantren Darussalam Martapura (tamat tahun 1977). Selama belajar di Martapura, selain belajar di Pesantren Darussalam, Guru Danau juga belajar dengan sejumlah ulama (tuan guru) yang bertebaran di Martapura. Salah satu ulama Martapura tempatnya belajar adalah Muhammad Zaini bin Abdul Ghani atau Guru Ijai (w. 2005), salah satu ulama karismatik yang disebut juga dengan nama Guru Sekumpul.

Setelah tamat di pesantren Darussalam, Guru Danau sempat pulang ke kampung halamannya. Tidak lama kemudian, pada tahun 1978, atas anjuran Guru Ijai dia kembali belajar di Pesantren Datuk Kalampaian Bangil di Jawa Timur. Di sini dia belajar dengan ulama Karismatik keturunan Syekh Muhammad Arsyad al-Banjari, yaitu Kyai Haji Muhammad Syarwani Abdan (w. 1989). Sebelum ke Bangil, Guru Danau terlebih dahulu ke Wonosobo menemui para habaib yang ada di sana dan mengambil tarikat Naqsyabandiyah dari salah seorang habaib bersama dengan Habib Lutfi Pekalongan. Setelah selesai belajar di Bangil, Guru Danau tidak segera pulang, dia terus 
memperdalam pengetahuan agamanya dengan mengunjungi dan belajar secara singkat kepada sejumlah ulama. Salah satu diantara ulama tempatnya belajar adalah Kyai Haji Abdul Hamid Pasuruan. Kegiatan belajar singkat dengan sejumlah ulama di Jawa ini dilakukan oleh Guru Danau untuk mendapat berkah ilmu dengan bertemu dan belajar kepada mereka. Hanya saja, studi Guru Danau di Pulau Jawa terutama di Bangil tidak berlangsung lama, hanya beberapa bulan. Dia kembali ke kampung halamannya untuk membuka pengajian.

Pada tahun 1980 Guru Danau menikah dengan Hj. Jamilah yang berasal dari Bitin. Inilah satu-satunya istri Guru Danau. Dia tidak ingin melakukan poligami seperti yang dilakukan oleh beberapa ulama Banjar lainnya. Baginya, tidak ada alasan untuk dirinya beristri lebih dari satu. Apalagi dari perkawinannya itu, dia memperoleh tiga belas orang anak (enam putra dan tujuh putri). Dengan anak sebanyak ini, Guru Danau merasa tidak perlu menambah istri.

Setelah berumah tangga dan memiliki anak, aktivitas dakwahnya tidak terganggu. Malah sebaliknya, aktivitasnya semakin meningkat. Dia semakin aktif mengisi pengajian dan mengajar di pesantren. Seiring dengan itu, namanya pun semakin dikenal dan jadwal ceramahnya juga semakin padat. Di sela-sela kesibukannya itu, Guru Danau tidak lupa untuk tetap belajar. Secara rutin dia tetap mengikuti pengajian Guru Ijai di Martapura baik ketika masih di Keraton maupun setelah pindah ke Sekumpul. Guru Danau terus mengikuti pengajian Guru Ijai sampai sang guru meninggal dunia pada tahun 2005.

Ketika ingin membuka pengajian, Guru Danau terlebih dahulu meminta izin kepada Guru Ijai. Sang Guru mengizinkan dengan syarat tidak boleh bapintaan (meminta dana dari masyarakat), harus memakai halat (dinding) yang memisahkan laki-laki dan perempuan, dan harus ikhlas. Agar seorang guru dapat ikhlas mengajar, dia harus memiliki kemandirian ekonomi. Dengan kemandirian ini, seorang guru dapat berkonsentrasi mengajar dan berdakwah tanpa mengharap imbalan uang.

Guru Danau membuka pengajian agama di Desa Bitin pada tahun 1978 (sebelum menikah) dan mengajar di Pesantren Salatiah. Pada tahun 1980, dia kembali membuka pengajian di kampung halamannya sendiri, Danau Panggang. Pada tahun-tahun awal, peserta pengajian Guru Danau di Bitin dan Danau Panggang tidak banyak. Bahkan, pada awal aktivitas dakwah dan pengajiannya itu, terdapat orang-orang tertentu yang tidak senang kepadanya. 
Dia difitnah sebagai penceramah yang keras dan suka mengomel. Fitnah ini bertujuan agar orang tidak mau belajar kepadanya dan tidak mau mendengar ceramahnya. Untuk menangkal fitnah ini, Guru Danau memanfaatkan radio orari yang ramai digunakan ketika itu untuk menampilkan citra dirinya. Setelah dua bulan masyarakat mendengar ceramahnya, mereka pun menemukan gaya ceramah Guru Danau yang sesungguhnya. Ternyata Guru Danau tidak sejelek yang mereka bayangkan. Bahkan sebaliknya, mereka justru tertarik mengikuti pengajian dan ceramahnya. Setelah fitnah itu terhenti dakwah melalui radio Orari ini dihentikan seiring dengan semakin bertambahnya jamaah yang menghadiri pengajiannya hingga lama-kelamaan mencapai ribuah orang.

Pengajian di Bitin dilaksanakan pada Sabtu malam (malam Minggu) sedang di Danau Panggang dilaksanakan pada Senin Malam. Di Bitin, pusat pengajian bertempat di rumah Guru Danau di sekitar Pasar Bitin. Rumah ini terbuat dari kayu yang sederhana. Ruang dalam rumah yang dipakai untuk pengajian tidak luas. Tidak banyak jamaah yang bisa ditampung dalam rumah ini. Hanya mereka yang menjadi murid dekat sang guru atau tamu khusus saja yang dapat berada di sini. Karena tidak ada lapangan yang luas, ribuan jamaah pengajian menempati teras dan halaman rumah penduduk sekitar. Banyak dari mereka yang duduk berbaris di pinggir-pinggir jalan hingga mencapai beberapa kilometer. Hal serupa juga terjadi pada pengajian di Danau Panggang. Pusat pengajian bertempat di Mushalla Darul Aman, yang tepat berada di samping rumah Guru Danau. Mushalla Darul Aman merupakan mushalla kecil yang hanya mampu menampung puluhan jamaah. Ribuan jamaah yang jumlahnya lebih besar dari pengajian di Bitin harus menempati teras dan halaman rumah penduduk sekitar serta ruas jalan yang ada. Demikian juga demikian dengan mesjid yang ada disekitar tempat pengajian itu.

Pada dekade 1990-an (1998), Guru Danau kembali membuka pengajian di Mabuun Tanjung (Kabupaten Tabalong). Pada awalnya, Mabuun merupakan sarang pelacuran dan perjudian. Guru Danau berusaha memberantas penyakit sosial ini dengan cara menghubungi pihak-pihak berwenang untuk menutupnya. Namun usaha ini tidak berhasil. Akhirnya, beliau membuka pengajian di tempat itu. Dengan adanya pengajian yang dihadiri oleh ribuan jamaah ini, praktik pelacuran dan perjudian itu berhenti dengan sendirinya. Pengajian di Mabuun ini kemudian menjadi pengajian Guru Danau yang terbesar karena dihadiri oleh puluhan ribu jamaah. Kuantitas jamaah yang hadir di tempat ini jauh lebih besar dibanding pengajian di Danau Panggang dan 
Bitin. Pengajian di Mabuun dilaksanakan pada malam Rabu setiap setengah bulan sekali. Jarak setengah bulan sekali (tidak seminggu sekali) dimaksudkan untuk memberikan kesempatan kepada jamaah pengajian untuk mengumpulkan uang untuk keperluan transportasi mendatangi tempat pengajian. Jamaah yang bertempat tinggal di kawasan Amuntai, Paringin, atau yang berada di kawasan Kalimantan Tengah (seperti Murung Raya) memiliki persiapan yang lebih luas untuk menghadiri pengajian di Mabuun. Komplek pengajian Guru Danau di Mabuun lebih luas dan lebih baik kondisinya dibanding pengajian di Bitin dan Danau Pannggang karena memiliki area yang lebih luas yang memungkinkan menampung puluhan ribu jamaah. Dengan kuantitas jamaah yang mencapai puluhan ribu jamaah ini, Pengajian Guru Danau di Mabuun disebut-sebut sebagai pengajian terbesar di kawasan Banua Anam.

Dengan jumlah jamaah pengajian yang begitu banyak, tidak aneh kalau murid Guru Danau tersebar di mana-mana di Banua Anam. Murid-murid Guru Danau terutama murid-murid awalnya sangat taat dan setia kepadanya. Bahkan, sebagiannya berkhadam (berkhidmat) kepadanya dengan setia. Jika Guru Danau bepergian ke suatu tempat untuk keperluan pengajian, ceramah, ziarah atau keperluan lainnya, murid-murid dekatnya selalu mengikutinya. Karena itu, tidak mengherankan jika konvoi iringan-iringan mobil rombongan Guru Danau mencapai puluhan bahkan seratus buah mobil. Jika rombongan ini melintas, segera menjadi perhatian masyarakat karena panjangnya iring-iringan itu. Bahkan, pernah Guru Danau mencarter dua pesawat untuk mengangkut dirinya dan rombongannya menuju Jakarta.

Selama bepergian ke beberapa daerah terutama di wilayah Kalimantan Tengah, Guru Danau sering berganti-ganti mobil saat dalam perjalanan. Mobil ketika pergi dan ketika pulang berbeda. Menurut Guru Danau, hal ini dia lakukan untuk kepentingan keamanaan. Dia mengungkapkan, bagaimanapun ada saja orang-orang yang tidak senang dengannya. Misalnya, dia mengaku telah berhasil mengislamkan 1400 orang Kristen Dayak di wilayah dakwahnya. Ini tentu membuat pastur-pastur Kristen marah dan tidak senang kepadanya. Karena itu, kalau Guru Danau melakukan perjalanan ke wilayah Kalimantan Tengah atau melewati kampung-kampung Dayak dia selalu berhati-hati. Orangorang yang tidak senang kepadanya bisa saja melakukan hal-hal yang tidak diinginkan seperti mencelakai dengan menggunakan parang maya (santet khas Dayak). 
Materi pengaiian yang disampaikan oleh Guru Danau di beberapa pengajiannya meliputi materi tauhid, fiqih, tasawuf, hadis, tafsir, kisah-kisah dan lainnya. Beberapa kitab yang pernah diajarkan oleh Guru Danau di pengajiannya, diantaranya adalah Irsyad al-Tbad (Zainuddin al-Malibari), Nasha ih al-Ibad (Nawawi al-Bantani), Muraqi al-Ubudiyyah (Nawawi alBantani), Risalah al-Mu'awanah (Abdullah al-Haddad), Nasha'ih al-Diniyyah (Abdullah al-Haddad), Tubfah al-Ragbibin (Muhammad Arsyad al-Banjari), Syarab Sittin (Ahmad Ramli), Tanqib al-Qawl (Nawawi al-Bantani). Dilihat dari daftar kitab yang digunakan, Guru Danau lebih banyak menggunakan kitabkitab berbahasa Arab daripada kitab Arab-Melayu. Walaupun begitu, pengajiannya tetap mudah diikuti oleh jamaah karena isi kitab-kitab itu diterjemahkan dan diberi penjelasan yang 'ringan' oleh Guru Danau.

Cara penyampaian Guru Danau dalam pengajian maupun ceramahnya cukup unik. Guru Danau termasuk ulama yang sangat humoris. Dalam setiap ceramah atau pengajiannya dia selalu menyampaikan cerita-cerita lucu, jokejoke, pantun-pantun, dan singkatan yang diplesetkan yang memancing tawa. Bahkan, Guru Danau tidak segan bercanda dengan murid-muridnya yang berada pada baris depan. Gaya ceramah seperti ini sedikit banyaknya diwarisi Guru Danau dari gurunya, Guru Ijai. Guru Ijai juga sering menyisipkan humor dalam penyampaian pengaiiannya termasuk bercanda dengan murid-murid pada lingkar terdepan pengajiannya. Bahkan, Guru Danau pernah mengatakan bahwa Guru Ijai itu lebih lucu (humoris) daripada dirinya. Baginya, humor itu penting disisipkan dalam ceramah pengajian agar orang awam dan orang tua dapat terus mengikuti pengajian tanpa merasa bosan dan berat.

Dalam menyajikan isi kitab pengajian, Guru Danau hanya membaca beberapa baris saja. Tetapi penjelasannya cukup luas dan terkadang tidak selalu terfokus dan relevan dengan substansi kitab atau teks yang dibaca karena banyak disisipi oleh cerita, humor, ilustrasi, canda dan sebagainya. Teknik seperti ini tampaknya sangat disukai oleh jamaahnya. Selain mendapat tuntunan, mereka juga mendapat 'hiburan' yang menyenangkan. Teknik ini merupakan salah satu daya tarik orang untuk menghadiri pengajian Guru Danau.

Cara penyampaian Guru Danau juga didukung oleh bahasa yang dominan digunakannya, yaitu bahasa Banjar. Bahasa ini merupakan bahasa yang digunakan mayoritas jamaahnya. Penggunaan bahasa lokal ini kemudian dibumbui dengan contoh-contoh dan Ilustrasi-ilustrasi yang pas dengan 
kondisi lokalitas sosiobudaya dan keseharian masyarakat sekitar sehingga isi ceramahnya sangat merakyat. Dengan cara seperti ini materi yang disampaikannya mudah dipahami oleh jamaahnya yang berasal dari berbagai lapisan sosial. Daya tarik Guru Danau tidak hanya terletak pada kemampuannya dalam berdakwah tetapi juga adanya persepsi umum bahkan kepercayaan dari jamaahnya bahwa orang-orang yang mengikuti pengajian Guru Danau dapat menjadi kaya atau paling tidak membawa berkah berupa rezeki yang bertambah. Beberapa murid dekatnya menjadi bukti nyata. Contohnya adalah murid sekaligus sopir pribadinya yang telah memiliki kekayaan yang mencapai empat milyar rupiah. Murid-murid awalnya bahkan menyebutnya sebagai wali Allah. Beberapa kisah kekeramatan mengenai Guru Danau yang berasal dari murid-muridnya banyak yang mengarah pada meningkatnya rezeki orang-orang yang mengikuti pengajiannya. Mereka yang mengaji dengannya akan memiliki usaha yang berhasil dan mampu naik haji. Peningkatan kesejahteraan jamaah pengikut pengajiannnya seringkali dihubungkan dengan berkah Guru Danau. Persepsi ini ditambah dengan isi ceramah Guru Danau sendiri yang banyak mengarahkan dan memotivasi jamaah pengajiannya untuk giat bekerja dan hidup mandiri. Guru Danau menganjurkan jamaahnya untuk mengikuti para nabi. Tidak ada satu pun nabi yang tidak bekerja dalam hidupnya. Mereka bekerja dan hidup mandiri.

Persepsi dan kepercayaan ini semakin terbangun dengan melihat pada figur Guru Danau sendiri sebagai ulama yang memiliki kekayaan dan penghasilan besar dari beberapa usaha bisnisnya. Dari beberapa bisnis Guru Danau yang terpenting adalah usaha emas dan sarang burung walet di daerah Tanjung. Usaha ini ternyata menghasilkan keuntungan besar. Dari usaha bisnis emasnya, Guru Danau berhasil memiliki emas mencapai 30 kilogram. Dari usaha sarang burung walet Guru Danau juga meraih keuntungan milyaran rupiah. Usaha burung walet ini dipelajarinya dari seorang habib di Jawa. Usaha lainnya adalah membeli tanah sebagai investasi. Tanah itu bisa dijual suatu saat. Dari beberapa usahanya ini, Guru Danau mengakui bisnis sarang burung walet lebih disukainya daripada bisnis emas karena lebih mudah dan menghasilkan untung yang banyak.

Dengan pendapatan yang besar dari bisnisnya, wajar jika Guru Danau menjadi orang kaya. Dia memiliki 22 buah rumah dan memiliki beberapa mobil mewah (dua buah mobil jenis Alphard). Dengan jumlah rumah sebanyak itu, dia dapat menyediakan rumah masing-masing untuk ketiga belas anaknya. 
Dengan mobil Alphard yang dimilikinya, dia dapat bepergian ke mana-mana dengan nyaman. Walaupun memiliki ini semua, Guru Danau tetap berpenampilan sederhana dan bersahaja. Rezeki yang cukup berlimpah ini tidak digunakan untuk bermegah-megah. Tetapi digunakannya untuk kepentingan dakwah Islam. Menurutnya, mereka yang mengurusi akhirat tidak seharusnya kalah dengan mereka yang mengurusi masalah dunia. Ulama yang memiliki usaha dan kekayaan sendiri akan lebih ikhlas dalam berdakwah dan mengajar karena tidak memiliki kepentingan untuk mendapat bayaran dari jamaahnya.

Dengan kemandirian dan kekayaan yang dimilikinya, Guru Danau dapat membiaya semua pembangunan komplek pengajian dan pesantren yang didirikannya tanpa bantuan pihak lain. Dia tidak mau meminta bantuan dana dari masyarakat (bapintaan) karena khawatir ada yang tidak ikhlas. Demikian juga dia tidak mau menerima dana yang berasal dari pemerintah dan partai politik. Menurutnya, jika satu kali saja mendapat bantuan pemerintah, ulama tidak bisa lagi untuk menasihati penguasa. Bahkan cenderung untuk dimanfaatkan oleh mereka yang memiliki kepentingan tertentu. Kemandirian inilah yang membuat dirinya tidak bisa diintervensi dan didikte oleh penguasa dan partai politik. Dia juga menolak dana atau bantuan dan hadiah yang tidak jelas sumber dan status kehalalalannya. Hadiah yang diberikan oleh para pejabat berupa mobil atau lainnya juga tidak diterimanya.

Meskipun tidak mau menerima pemberian atau bantuan pemerintah dan menjaga jarak dengan partai politik, Guru Danau tetap dekat dengan sejumlah pejabat. Dia bersedia menghadiri undangan ceramah dari para bupati dan gubernur dengan syarat pejabat yang bersangkutan menghadirinya. Dia tidak segan-segan memuji pejabat yang menurutnya memiliki reputasi baik dan sebaliknya juga tidak segan-segan memberi nasihat kepada pejabat yang menurutnya melalaikan kepentingan rakyat. Dia sering menasihati pejabat agar membuat jalan raya yang bagus untuk rakyat daripada hanya membangun perkantoran. Jalan yang baik jelas dinikmati rakyat tetapi kantor yang mewah hanya dinikmati oleh para pejabat.

Selain memiliki tiga pengajian besar, Guru Danau juga mendirikan dan membina beberapa pesantren. Pada tahun 1982, ia mendirikan pesantren Darul Aman di Kecamatan Babirik (Hulu Sungai Utara). Sampai saat ini pesantren ini tetap berjalan dan pada tahun 2011 ini jumlah santrinya mencapai 800 orang. Nama Darul Aman sendiri mengikuti nama Langgar Darul Aman di Keraton tempat Guru Ijai mengajar. Guru Danau juga menamai mushalla di samping 
rumahnya dengan nama Darul Aman, sama dengan nama langgar gurunya di Keraton Martapura. Pesantren lain yang dibinanya adalah Pesantren Raudatus Sibyan di Desa Longkong Kecamatan Danau Panggang dan Pesantren Ar Raudah I di Jaro Tabalong dan Ar Raudah II di Pangkalanbun. Jadwal dan mobilitas dakwahnya yang padat membuat Guru Danau tidak memiliki waktu yang cukup untuk aktif mengajar di pesantren. Area dakwahnya yang meliputi wilayah Kalimantan Selatan, Tengah dan Timur tidak memungkinkannya untuk mengajar secara rutin di pesantren. Akhirnya, aktivitas mengajarnya di pesantren digantikan oleh guru-guru staf pengajar Pesantren Darul Aman.

Aktivitas lain yang juga banyak menyita waktunya adalah menerima tamu dengan berbagai kepentingan. Setiap harinya rumah beliau banyak dikunjungi tamu dari berbagai daerah. Mereka yang bertamu ini berasal dari berbagai lapisan mulai dari pejabat, ulama, politisi, kalangan akademis, pengusaha hingga rakyat biasa. Mereka datang dengan berbagai kepentingan. Para pejabat yang datang paling tidak untuk silaturahmi, mohon doa, dukungan, atau memberi hadiah (walaupun ditolak). Politisi biasanya meminta dukungan dan ajakan kepadanya untuk masuk partai. Tawaran seperti ini selalu ditolak oleh Guru Danau. Dia tidak mau berpolitik dan tidak mau dimanfaatkan untuk kepentingan politik partai tertentu. Sementara kalangan masyarakat awam biasanya datang untuk berkonsultasi mengenai berbagai masalah baik masalah agama, masalah bisnis dan masalah keseharian lainnya. Ada juga sejumlah orang yang datang sambil membawa botol air mineral (aqua) dan disodorkan kepadanya untuk dibacakan doa tertentu. Ketika tim peneliti berkunjung ke rumahnya pada tanggal 27 November 2011 di Danau Panggang, sejumlah tamu yang berkunjung kepadanya justru berkonsultasi mengenai bagaimana cara mengelola sarang burung walet yang baik agar dapat membuahkan hasil yang maksimal. Konsultasi seperti ini tidak mengherankan karena dia merupakan pengusaha sarang burung walet yang sukses.

Untuk kepentingan melayani tamu yang berkunjung kepadanya, Guru Danau menyediakan waktu-waktu tertentu. Pada hari Minggu waktu yang disediakan mulai pukul sebelas sebelum zuhur. Pada hari Senin, Selasa, Rabu dan Kamis, Guru dapat dikunjungi setelah salat zuhur hingga menjelang ashar. Itupun kalau Guru Danau tidak melakukan kunjungan dakwah atau mengisi ceramah di tempat lain. Para tamu yang datang harus menyesuaikan kedatangannya dengan waktu-wkatu yang telah disediakan itu karena dia jarang 
ada di rumah. Prinsip hidupnya, tiada hari tanpa dakwah, membuatnya harus selalu berada di mana-mana di tengah-tengah jamaahnya.

\section{Figur Guru Zuhdi}

K. H. Ahmad Zuhdiannor dilahirkan di Banjarmasin pada 10 Februari 1972 dari keluarga yang menekuni ilmu-ilmu agama. Beliau merupakan putera dari H. Muhammad bin Jafri dan Hj. Zahidah binti K.H. Asli. Ayah beliau dikenal sebagai ulama yang cukup terkenal di Banjarmasin. Sedangkan kakek beliau dari pihak Ibu, K.H. Asli adalah tokoh ulama yang berdomisili di Alabio. Keduanya nanti terlibat secara penuh dalam pendidikan Zuhdi kecil.

Beliau memiliki sembilan orang saudara. Dua orang di antaranya sudah meninggal, sehingga ada tujuh orang yang masih hidup. Nama-nama saudara beliau, Hj. Naqiah, Sa'aduddin, Jahratul Mahbubah, As'aduddin, Zulkifli, Najiah, Nashihah, dan Nafisah.

Pendidikan formal yang dijalani Ahmad Zuhdiannor hanya sampai tingkat SD. Setelah itu, beliau melanjutkan ke Pesantren Al Falah, selama sekitar dua bulan, namun karena sakit kemudian berhenti. Kemudian beliau belajar dari kakek beliau sendiri dari pihak ibu, K.H. Asli selama satu tahun. Bidang ilmu yang dipelajari di sana, yaitu Ilmu Tajwid, Fikih, Tashrif, Tauhid, Tasawuf. Setelah satu tahun di Alabio, kemudian meneruskan mengaji dengan orang tuanya, belajar Tauhid, Fikih, Nahwu, Tasawuf. Selama di Banjarmasin, beliau juga belajar dengan K. H. Abd. Syukur Teluk Tiram, di sana dia belajar tasawuf, fikih, ushul fikih, Arudh. Setelah meninggal K.H. Abd. Syukur kemudian menambah lagi ilmu dengan K. H. Muhammad Zaini bin Abdul Ghani (Guru Sekumpul), dengan beliau belajar beberapa ilmu, terutama akhlak kurang lebih selama tujuh tahun. Pengaruh Guru Sekumpul terhadap Guru Zuhdi sangat kuat. Pada banyak hal beliau selalu merujuk kepada figur sang guru ini, seperti dalam hal tarekat, beliau mengikuti Tarekat Sammaniyah. Bahkan dalam berpakaian pun ketika mengisi pengajian, beliau sangat mirip dengan ulama kharismatik asal Martapura ini, yakni baju putih dengan serban besar di kepala.

Kitab-kitab yang beliau pelajari selama nyantri yaitu: Pada bidang tauhid, Syarah Hud Hudi karya Imam Syarkawi, Syarah Dasuqi karya Imam Sanusi, Matan Sanusiah karya Imam Sanusi, dan Kifayatul Awal, karya Syekh Fudhali. Pada bidang tasawuf, Bidayatul Hidayah karya Imam Ghazali, 
Minhajul Abidin karya Imam Ghazali, Ihya Ulumuddin karya Imam Ghazali, dan Taqribul Ushul karya Syekh Zaini Dahlan. Pada bidang fikih, Syarah Sitin karya Syekh Ramli, Syarah Bajuri karya Syekh Bajuri, dan Syarah I'anatuthalibin karya Syekh Zainuddin. Sedangkan pada ilmu nahwu, Matan Jurumiah karya Imam Sanhaji, Mukhtasar Jidan karya Syekh Zaini Dahlan, Syarah Syekh Khalid karya Syekh Khalid, dan Alfiah Ibnu Malik karya Ibnu Malik.

K. H. Ahmad Zuhdiannor pernah mengajar selama sekitar dua tahun di Pondok Pesantren Al Falah. Aktivitas beliau sekarang ini yaitu membuka pengajian di Mesjid Jami pada Malam Ahad, pengajian di rumah Guru Zuhdi pada Malam Sabtu, pengajian di Teluk Dalam, Langgar Darul Iman malam selasa, dan pengaiian di Sabilal Muhtadin pada malam Jum'at. Beliau biasanya tidak bersedia di undang pada peringatan hari-hari besar Islam, dan hanya memfokuskan diri pada pengajian saja.

\section{Menjadi Ulama Kharismatik}

Di Bab II kita telah menelaah sejarah ulama-ulama Banjar yang berpengaruh luas, dan sebagian besar dari mereka tak diragukan lagi tergolong ulama kharismatik. Sementara pada Bab III ini, di atas sudah dipaparkan latar belakang biografis dan aktivitas tiga ulama Banjar masa sekarang yang tergolong kharismatik. Pertanyaan yang menggoda kemudian adalah, mengapa tiga orang ulama ini menjadi tokoh kharismatik? Untuk menjawab pertanyaan ini, kita akan menggunakan kerangka teori yang telah dikemukakan pada Bab I sebagai acuan untuk menafsirkan data biografis dan aktivitas ketiga ulama tersebut.

Menurut Weber, seorang tokoh kharismatik adalah orang yang dipercaya memiliki keistimewaan, kekuatan luar biasa, bahkan bersifat supernatural. Ketiga tokoh ini jelas dipercaya para pengikutnya memiliki keistimewaan semacam itu. Jalan ke arah ini memang sudah ada, yaitu tradisi tasawuf. Ketiga tokoh ini aktif mengajarkan tasawuf, dan oleh murid-muridnya dikagumi dan diikuti sebagai seorang sufi. Di dalam tasawuf, ada kepercayaan yang kuat bahwa seorang yang dekat dengan Tuhan, pada saat tertentu, bisa dianugerahi keramat, suatu keistimewaan yang melampaui hukum alam atau kemampuan rata-rata manusia. Sebagaimana ulama-ulama Banjar sebelumnya sejak Arsyad al-Banjari, ketiga tokoh ini dipercaya memiliki keistimewaan semacam itu. Guru Danau misalnya, dipercaya oleh murid-muridnya sebagai 
wali, sehingga ia dapat mengetahui apa yang bakal terjadi (misalnya siapa yang nanti akan menang dalam Pilkada). Mengikuti pengajiannya secara rutin, juga dipercaya akan mendatangkan kemakmuran hidup. Pedagang yang bangkrut akan bangkit kembali usahanya, dan orang miskin akan mendapatkan jalan tak disangka-sangka untuk bisa naik haji. Guru Bachiet juga dipercaya memiliki tingkat spiritualitas yang tinggi. Salah satu yang dikemukakan oleh orang dekatnya adalah, beliau selalu berkomunikasi dengan ayahandanya, minimal dua kali seminggu, meskipun sang ayah sebenarnya sudah wafat. Guru Zuhdi, sebagai tokoh yang paling muda dan muncul di masyarakat urban Banjarmasin, ia tidak/belum dibanggakan murid-muridnya sebagai orang yang memiliki karamah. Tetapi justru di situlah letak kekuatannya. Ia bisa tampil di masyarakat perkotaan sebagai figur yang dikagumi dan menyentuh hati.

Keistimewaan tiga tokoh ini juga terletak pada konsistensi mereka, yang dikagumi oleh para pengikutnya. Guru Zuhdi, yang sering mengajarkan tauhid dan tasawuf, dan menekankan betapa pentingnya membersihkan hati, tampil sebagai tokoh rendah hati yang tulus. Ia juga konsisten di jalur agama, tidak mau ikut dalam permainan politik, seperti mendukung politisi tertentu dalam pemilu. Guru Bachiet dikagumi karena konsistensinya mengajarkan kitab-kitab klasik dalam pengajian-pengajiannya. Ia menegaskan kepada murid-muridnya, bahwa guru yang sebenarnya adalah kitab-kitab itu, sementara dirinya hanyalah membacakan dan menjelaskan saja. Ini suatu kerendahan hati, sekaligus menunjukkan bahwa ia tidak mau pengajiannya ditaburi lelucon rendahan. Sementara itu, Guru Danau, meskipun suka menggunakan humor-humor yang kadang 'nakal' (yang sebenarnya biasa dalam budaya Banjar), dia menunjukkan suatu konsistensi yang penting kepada murid-muridnya, yaitu kemandirian. Ia adalah seorang yang pandai berbisnis, sehingga hidupnya tidak tergantung pada amplop pemberian masyarakat atau politisi. Ia bahkan mengeluarkan uangnya sendiri untuk menjalankan dakwahnya. Lebih dari itu, ia juga berpendapat bahwa penampilan seorang ulama harus mengesankan, agar dakwah tidak diremehkan orang. Maka ia tak segan-segan membanggakan mobil mewah yang dipakainya, dan perjalanannya ke suatu tempat yang agak jauh biasanya dikawal oleh polisi dengan iring-iringan mobil para pengikutnya.

Selain itu, tokoh kharismatik adalah pemimpin yang lahir di masa krisis, dan mencoba menawarkan jalan keluar. Secara umum, masyarakat Banjar, sebagaimana masyarakat Indonesia lainnya, terus menghadapi berbagai krisis sosial seperti pengangguran, korupsi, dekadensi moral, dan sebagainya. 
Sementara itu, terjadi pula krisis kepemimpinan ulama, khususnya ulama kharismatik. Sejak wafatnya Guru Sakumpul tahun 2005, masyarakat Banjar tradisional tampaknya benar-benar kehilangan figur ulama tempat bersandar. Krisis ini membuka peluang bagi munculnya tokoh-tokoh baru. Dua dari tiga ulama yang ditelaah di sini, menunjukkan identifikasi diri yang amat kuat kepada Guru Sakumpul, yaitu Guru Danau dan Guru Zuhdi. Guru Danau mengatakan, ia memiliki hubungan yang amat dekat dengan Guru Sakumpul (yang menggelarinya 'Menteri Perikanan' karena ia berasal dari Danau Panggang, tempat yang banyak ikannya). Bahkan menurut Guru Danau, untuk membuka majelis taklim pun, ia selalu meminta izin terlebih dahulu kepada Guru Sakumpul. Dalam ceramah-ceramahnya, cerita tentang Guru Sakumpul seringkali muncul. Guru Danau juga menamai langgar di tempatnya dengan 'Darul Aman', sama dengan nama langgar di Keraton, tempat Guru Zaini mengajar sebelum pindah ke Sakumpul. Hal yang serupa juga dapat ditemukan pada Guru Zuhdi. Ia bukan saja banyak belajar kepada Guru Sakumpul, melainkan juga berpakaian (terutama lilitan serbannya), dan nada berbicaranya, mirip sekali dengan Guru Sakumpul. Maka boleh dikatakan, kedua tokoh ini seolah mengisi kekokosongan yang ditinggalkan Guru Sakumpul, dengan kehadiran mereka sebagai orang dekat sang Guru.

Di sisi lain, Guru Bachiet tampaknya memiliki karakter berbeda. Ia sama sekali tidak menonjolkan hubungannya dengan Guru Sakumpul sebagai murid. Cerita tentang penolakannya beberapa kali terhadap panggilan Guru Sakumpul untuk bertemu, jelas menegaskan akan hal ini. Maka Guru Bachiet tampaknya dipercaya oleh murid-muridnya, bukan sebagai orang yang berada di bawah Guru Sakumpul, melainkan sejajar dengannya. Guru Bachiet hanya tunduk pada ayahandanya, Guru Amat Nagara, yang juga tokoh kharismatik, meskipun ia telah meninggal dunia. Jika kita mengikuti teori Weber tentang kharisma, maka figur Guru Bachiet lebih mendekati kepada kharisma yang sejati, karena tokoh kharismatik bagi Weber adalah seorang perintis, orang yang memulai sesuatu yang baru, dan kalau perlu menolak yang lama. Tokoh kharismatik yang ideal adalah orang yang menjadi dirinya sendiri, tidak meniru tokoh sebelumnya. Maka jika dilihat dari konteks krisis tokoh ulama menyusul wafatnya Guru Sakumpul, Guru Bachiet tidaklah 'meneruskan' melainkan 'menggantikan'.

Namun ada hal lain yang, bagaimanapun, menunjukkan bahwa ketiga orang ini, menjadi kharismatik antara lain karena faktor geneologis. Guru 
Danau sendiri, dari jalur ibunya, adalah keturunan Syekh Arsyad al-Banjari, melalui tokoh ulama Marabahan, Qadhi Abdusshamad. Jalur keturunan ini ditegaskan sendiri oleh Guru Danau kepada tamu-tamunya, ketika kami menemuinya di rumahnya. Menurutnya, krisis ekonomi yang menimpa wilayah Marabahan mendorong keluarganya untuk merantau hingga sampai ke daerah Danau Panggang, di mana ia menetap sekarang. Ini kemudian ditafsirkannya sebagai rencana ilahi, karena ia kemudian dapat berdakwah ke daerah yang lebih hulu, kepada orang-orang Dayak, sebagaimana leluhurnya dahulu, Qadhi Abdusshamad, berdakwah kepada orang-orang Dayak Bakumpai. Patut dicatat di sini bahwa, garis keturunan dari Arsyad al-Banjari, yang diterima luas, ternyata bukan hanya melalui jalur ayah, melainkan juga jalur ibu, sebagaimana yang terjadi pada Guru Danau. Adapun Guru Bachiet, ia adalah keturunan yang amat dekat (keenam) dengan Arsyad al-Banjari, melalui jalur ayahnya yang juga seorang ulama besar. Meskipun ia sendiri tidak mau menonjolkan faktor geneologis ini, tetapi murid-murid dekatnya sudah mafhum. Sedangkan Guru Zuhdi, ia memang bukan keturunan al-Banjari, tetapi ia sendiri adalah anak seorang ulama yang dihormati, Tuan Guru Haji Muhammad, yang pernah menjadi pimpinan puncak Pondok Pesantren Al-Falah, Banjarbaru, sebuah pesantren yang memiliki ribuan alumni dan santri. Paman Guru Zuhdi adalah Tuan Guru H. Muhammad Sani, yang dikenal dengan sebutan 'Guru Tani', adalah ulama terkemuka di Banjarmasin, dan pendiri Pondok Pesantren AlFalah.

Jika kita merujuk kepada teori Weber, maka kita akan menemukan kesulitan perihal kharisma yang diwariskan ini. Weber memang mengakui bahwa kharisma itu ada yang bersifat kekeluargaan, tetapi menurutnya, kharisma yang diwariskan akan mudah redup. Namun jika kita melihat fenomena tiga ulama kharismatik ini, maka kita tak bisa menolak bahwa faktor keturunan bisa menjadi dasar bagi terciptanya kharisma. Tentu saja, jika hanya faktor keturunan satu-satunya yang ditonjolkan, kharisma mungkin tidak akan bertahan. Faktor-faktor lain, terutama kemampuan sang tokoh merespon kebutuhan-kebutuhan masyarakatnya, mungkin lebih menentukan ketimbang faktor keturunan. Hal ini mungkin pula dapat menjelaskan, mengapa Guru Zuhdi yang secara garis keluarga tidak berhubungan langsung dengan alBanjari, tetapi sedikit banyak dapat 'mewarisi' kharisma Guru Sakumpul. Ia dianggap demikian karena penampilan dan sikapnya amat mirip dengan sang Guru. Maka kerinduan masyarakat pada Guru Sakumpul, seolah terobati dengan penampilan Guru Zuhdi. 
Selain itu, Weber juga menegaskan bahwa kharisma lahir karena keistimewaan sang tokoh yang dapat mewujudkan keajaiban-keajaiban. Tetapi karena keajaiban itu tidak selalu terjadi, maka kharisma akan memasuki rutinisasi dan pelembagaan. Hal serupa tampaknya memang terjadi pada ketiga tokoh kita ini. Rutinisasi itu tampak jelas pada pengaiian-pengajian yang mereka isi secara rutin, dengan jemaah yang lebih kurang rutin juga. Ada ritus-ritus yang rutin dikerjakan, seperti salat hajat berjamaah, membaca maulid al-Habsyi dan ceramah. Jemaah mereka umumnya adalah jemaah yang setia. Bahkan ke manapun Guru pergi, mereka ikut menemani, lebih-lebih orang-orang yang berada pada lingkaran terdekat. Kesetiaan para murid ini melahirkan tokoh kharismatik yang terorganisir, meskipun tidak formal. Ada orang-orang dekat, yang menjadi perantara, sekaligus menjaga jarak, antara Guru dan para tamunya. Untuk menciptakan rutinisasi ini, Guru Danau cenderung menuntut agar para muridnya menghadiri langsung pengajian-pengajiannya. Ia tidak mau menggunakan radio atau televisi. Tak ada juga transkripsi ceramahnya. Sebaliknya, Guru Bachiet menggunakan segala media komunikasi modern. Murid-muridnya mentranskrip cerramah-ceramahnya untuk disebarluaskan. Ada pula berbagai VCD ceramahnya beredar di pasar. Ia juga tampil di televisi lokal. Adapun Guru Zuhdi, ia kadang-kadang juga tampil di televisi, dan ceramahnya disiarkan luas melalui radio. Semua ini merupakan rutinisasi.

\section{Penutup}

Tiga ulama Banjar yang dibahas dalam penelitian ini, jelas menunjukkan ciri-ciri seorang tokoh kharismatik berdasarkan teori kharisma dalam sosiologi. Mereka adalah tokoh-tokoh yang memiliki keistimewaan, dan tampil di saat krisis, baik krisis sosial yang tengah terjadi, ataupun krisis kepemimpinan ulama setelah wafatnya ulama kharismatik terkemuka di Kalimantan Selatan, Guru Zaini bin Abdul Ghani, yang dikenal dengan Guru Sakumpul. Masing-masing tokoh memiliki pesona, yang mampu memukau ribuan khalayak yang setia mendengarkan ceramah-ceramahnya. Ia seolah memiliki kekuatan magnetik, yang menyerap orang-orang di sekelilingnya untuk medekat.

Meskipun sama-sama memiliki kharisma, masing-masing tokoh memiliki keunikannya sendiri-sendiri. Latarbelakang sejarah intelektual mereka memang tidak sama, meskipun secara garis besar masih berada dalam jalur keulamaan tradisional. Mereka juga menjadi tokoh di wilayah yang berbeda, dengan jemaah yang berbeda pula (meskipun kadang-kadang bisa saja terjadi tumpang tindih jemaah). Guru Zuhdi adalah tokoh di Banjarmasin, kota yang 
semakin padat dan metropolis, sedangkan Guru Bachiet di Barabai dan Balangan, sementara Guru Danau di pinggiran Kabupaten HSU (Danau Panggang dan Bitin) dan Kota Tanjung.

Kharisma masing-masing tokoh pada gilirannya terpelihara melalui rutinisasi, baik melalui tatap muka langsung di pengajian ataupun penggunaan media cetak dan elektronik modern. Mereka hadir di ruang publik sebagai tokoh dan pemimpin agama yang didengarkan petuah-petuahnya. Namun sejauh ini, meskipun mereka menggunakan media modern, pengaruh mereka tampaknya lebih kuat tertanam melalui pengajian tatap muka. Mungkin ini sekali lagi menunjukkan bahwa, tak ada satupun dari mereka yang kini menduduki posisi setingkat dengan Guru Sakumpul, yang pengaruhnya tersebar luas di Kalimantan Selatan. Di sisi lain, tiga tokoh ini tampaknya menunjukkan pergeseran pusat kharisma, dari Martapura di mana Guru Sakumpul menetap, menyebar ke tiga wilayah: Banjarmasin, Barabai, Tanjung. Masih terlalu dini untuk memperkirakan, siapakah salah satu dari tiga tokoh ini yang kelak akan menempati posisi kharismatik yang lebih luas dan besar di masa yang akan datang. Dari segi keunikan, barangkali Guru Bakhiet memiliki peluang untuk itu. Hanya saja, pengaruhnya tampaknya masih di wilayah Hulu Sungai, belum merambah kepada dua wilayah Hilir yang amat penting: Kabupaten Banjar dan Kota Banjarmasin.

\section{DAFTAR PUSTAKA}

Abdullah, Wan Muhd. Shaghir. 1990. Syeikh Mubammad Arsyad al-Banjari Pengarang Sabilal Mubtadin. Kuala Lumpur: Khazanah Pathaniyah.

Anwar, Khairil, dkk. 2006. Kedatangan Islam di Bumi Tambun Bungai. Palangkaraya: STAIN Palangkaraya.

Aride, BR., M., et. al. 2000. Masjid Agung Al Karomah Martapura. Martapura: Kantor Departemen Agama Kabupaten Banjar dan Pemerintah Kabupaten Banjar.

Bondan, Amir Hasan. 1953. Suluh Sedjarah Kalimantan Bandjarmasin: Pertjetakan Fadjar. 
Dahlan, Muhammad Abrar. 2004. Biografi Singkat KH. Mabfuz, Amin dan Sejarah Pondok Pesantren Ibnul Amin Pamangkih Cetakan III. Pamangkih: PP Ibnul Amin.

Daudi, Abu. 2003. Maulana Syekh Mubammad Arsyad al-Banjari (Tuan Haji Besar) Edisi Baru. Martapura: Yapida.

Daudi, Abu. 2006. Al-'Alim al-'Allamah al-Arif bi Allah al-Syaykh Hajj Mubammad Zayni ibn Abdul Gani. Martapura: Yapida.

Daudi, Abu. tth. Manakib Alim Allamah Qadbi Haji Abd Samad Marabahan, naskah manakib tidak diterbitkan.

Feith, Herbert. 1999. Pemiliban Umum 1955 di Indonesia. Terj. Nugroho Katjasungkana, Masri Maris dan Prakitri Simbolon Jakarta: Kepustakaan Populer Gramedia.

Hidayat, Kamarul, Apa dan Siapa dari Utara: Profil dan Kinerja Anak Banua,Jakarta, CV Surya Garini, th.

Hosikoshi, Hiroko, 1987, Kyai dan Perubahan Sosial, Terj. Djohan Effendi dan Muntaha Azhari, Jakarta: P3M.

Hudhari, Muhammad. 2004. Manaqib Mawlana Syekh Mubammad Arsyad bin Abdullah al-Banjari. t.tp.

Mandan, Arief Mudatsir ed. 2008. Napak Tilas Pengabdian Idham Chalid Jakarta: Pustaka Indonesia Satu.

Miles, Douglas. 1976. Cutlass and the Crescent Moon: A Case Study of Social and Political Change in Outer Indonesia Sydney: Center for Asian Studies, University of Sydney.

Muhajir, Ahmad. 2007. Idham Chalid, Guru Politik Orang NU Yogyakarta: Pustaka Pesantren.

Muhajir, Ahmad. 2009. "Tuan Guru and Politics in South Kalimantan: Islam in the 2005 Gubernatorial Elections." MA Thesis. Faculty of Asian Studies, ANU. Tidak Diterbitkan.

Munawwar. Tth. Nûr al-Abshâr fì Dæìkr Nubdそ̧at min Manâqib al-Syaykh Mubammad Kasyful Anwar. Martapura: Majelis Taklim Mushalla Raudhtul Anwar. 
Nihra, 2001. "Aktivitas Dakwah Islamiah K.H. Asmuni di Kecamatan Danau Panggang Kabupaten Hulu Sungai Utara". Skripsi. Banjarmasin: Fakultas Dakwah IAIN Antasari.

Potts, John. 2009. A History of Charisma. New York: Palgrave Macmillan.

Rahmadi. 2010. Jaringan Intelektual Ulama Banjar Abad XIX dan XX (Studi tentang Proses, Pola dan Ekspansi Jaringan). Banjarmasin: Antasari Press.

Ras, J.J. 1968. Hikajat Bandjar: A Study in Malay Historiography The Hague: Martinus Nijhoff.

Saifuddin, Achmad Fedyani. 1986. Konflik dan Integrasi, Perbedaan Fabam dalam Agama Islam Jakarta: Rajawali Pers.

Sjamsuddin, Helius. 2001. Pegustian dan Temenggung: akar sosial, politik, Etnis dan Dinasti Perlawanan di Kalimantan Selatan dan Tengah. Jakarta: Balai Pustaka.

Sjamsuddin, Helius. 2001. Pegustian dan Temenggung: akar sosial, politik, Etnis dan Dinasti Perlawanan di Kalimantan Selatan dan Tengah. Jakarta: Balai Pustaka.

Steenbrink, Karel A. 1984. Beberapa Aspek Tentang Islam di Indonesia Abad ke-19 Jakarta: Bulan Bintang.

Suryadinata, Leo. Evi Nurvidya Arifin dan Aris Ananta. 2003. Indonesia's Population: Ethnicity and Religion in a Changing Political Landscape. Singapore: ISEAS.

Syaharuddin. 2008. "Organisasi Islam di Borneo Selatan, 1912-1942: awal kesadaran berbangsa urang Banjar." Tesis Master. Yogyakarta: Fakultas Ilmu Budaya, Universitas Gadjah Mada. Tidak Diterbitkan.

Tim IAIN Antasari. 1989. "Pemikiran-Pemikiran Keagamaan Syekh Muhammad Arsyad al-Banjari" Proyek Peningkatan Mutu Perguruan Tinggi Agama Islam, IAIN Antasari. Tidak Diterbitkan.

Tim Sahabat. 2010. 27 Ulama Berpengaruh Kalimantan Selatan. Kandangan: Toko Buku Sahabat.

Wajidi. 2007. Nasionalisme Indonesia di Kalimantan Selatan 1901-1942 Banjarmasin: Pustaka Banua.

Weber, Max. 1958. From Max Weber: Essays in Sociology. Terj. H.H. Gerth dan C. Wright Mills. New York: Oxford University Press. 
Weber, Max. 1964. The Sociology of Religion Terj. Ephraim Fischoff. Boston: Beacon Press. 